\title{
Inhibition of Toll Like Signaling Pathway Is Associated With Genomic Instability in Rat Liver Exposed to Crack Cocaine
}

\author{
DANIEL VITOR DE SOUZA, BARBARA DOS ANJOS ROSARIO, LAIS VALES MENNITTI, \\ INGRA TAIS MALACARNE, LUCIANA PELLEGRINI PISANI, REGINA CLAUDIA \\ BARBOSA DA SILVA, MILENA DE BARROS VIANA and DANIEL ARAKI RIBEIRO \\ Department of Biosciences, Institute of Health and Society, \\ Federal University of Sao Paulo, UNIFESP, Santos, SP, Brazil
}

\begin{abstract}
Background/Aim: The aim of the present study was to investigate the biological effects of subacute crack cocaine exposure in rat liver. Material and Methods: A total of 32 rats were distributed into four groups $(n=8)$ : Experimental group $1(G 1)$ and Experimental group $2(G 2)$ : rats received $18 \mathrm{mg} / \mathrm{kg}$ of body weight (b.w) of crack cocaine for 5 days, once a day, group G2 remained $72 h$ without exposure after the experimental period (5 days)(abstinence); Experimental group 3 (G3): rats received $36 \mathrm{mg} / \mathrm{kg}$ of body weight (b.w) of crack cocaine for 5 days, once a day; Control Group (CTRL): rats received only the vehicle (DMSO) administered by the intraperitoneal (i.p) route for 5 days, once a day. Results: All groups exposed to crack cocaine had an increase in the number of micronucleated hepatocytes and binucleated cells only in the highest tested dose (36 mg/kg). Karyolysis had an increase in the $18 \mathrm{mg} / \mathrm{kg}$ dose, in the abstinence group (G2), and $36 \mathrm{mg} / \mathrm{kg}$ group (G3); whereas pyknotic nuclei had an increase in the G2 group. The group exposed to $18 \mathrm{mg} / \mathrm{kg}$ of crack cocaine also showed high 8 OHdG expression. The $p-N F-k B$ p65 protein decreased in the groups exposed to crack cocaine at doses of 18 and $36 \mathrm{mg} / \mathrm{kg}$, as well as in the abstinence group. MyD88 was also found decreased in the group exposed to crack cocaine at $18 \mathrm{mg} / \mathrm{kg}$. Conclusion: Crack cocaine inhibited toll like signaling pathway whilst being associated with genomic instability in rat liver cells.
\end{abstract}

This article is freely accessible online.

Correspondence to: Daniel Araki Ribeiro, Department of Biosciences, Federal University of Sao Paulo, UNIFESP, Rua Silva Jardim, 136, Room 332, Vila Mathias, Santos, SP 11050-020, Brazil. Tel/Fax: +55 1332290156, e-mail: daribeiro@unifesp.br

Key Words: Crack cocaine, micronucleus, toll like signaling pathway, genomic instability, liver.
Crack cocaine is cocaine in the most harmful form, due to the presence of such remnants (adulterants), which are continuously used through refinement process (1). Usually, crack cocaine is presented in the form of base. The name "crack" is frequently used due to the onomatopoeic expression that refers to the crackling sound generated during pyrolysis, when the drug is consumed by smoking route (2).

Crack cocaine was first seen in Brazil in the early 90s, where it gained great popularity. Nowadays, the largest use and dissemination of crack cocaine across the country have been seen as a major public health problem, due to the severe dependence caused by using the illicit drug. As a result, risk behaviors and acts of violence are frequently observed in crack cocaine users. Such behaviors affect society as a whole, putting the health and safety of the population at risk (3). There is a high prevalence of crack cocaine users visiting health services around the world. In the United States of America (USA), crack cocaine is responsible for the largest number of visits to health services due to the use of illicit drugs. In Brazil, the same condition exists, with the attendance at these services being increasingly frequent due to the indiscriminate use of crack cocaine (4).

To date, few studies have reported the toxicity induced by crack cocaine in multiple organs and tissues. Previous studies conducted by our research group have demonstrated that acute doses of crack cocaine are able to induce genetic damage in multiple organs of rodents $(5,6)$. In humans, crack cocaine was able to increase the number of micronucleated cells of exfoliated oral mucosa cells as a result of chromosome breakage or loss $(7,8)$.

Toll like signalling pathway plays a pivotal role in the activation of immune system being responsible for protecting the living organism. Initiation of the toll like signalling pathway, occurs by MyD88 activating the interleukin receptor-associated kinases IRAK1 and IRAK4, which in turn stimulates the tumour necrosis-associated factor TRAF- 
6 adapter protein, triggering the NFkBp50 and NFkBp65 dimers (9). Finally, NFkB goes to the nucleus and controls the expression of some pro-inflammatory cytokines, such as TNF- $\alpha$ (9). In fact, recent studies have shown that some toll like receptors mediate the inflammatory response in the hippocampus of mice exposed to cocaine (10). Others have reported that toll like receptor 3 plays a crucial role in cocaine addiction as a result of pro-inflammatory immune signaling in the central nervous system (11). However, to the best of our knowledge, there are no studies to address if and to what extent, toll like signaling pathway is modulated in rat liver cells exposed to crack cocaine in vivo.

The aim of the study was to investigate if sub-acute crack cocaine exposure would be able to interfere with toll like signaling associated or not with genetic damage in the rat liver in vivo.

\section{Materials and Methods}

Animals and experimental design. All procedures were conducted according to the International Research Standards for Animals, and approved by the Animal Ethics Committee of the Federal University of Sao Paulo, UNIFESP, SP, Brazil (protocol no. 7038080219). The crack cocaine sample used in the present research has already undergone a chemical analysis in previous studies by our research group (5). A total of 32 Wistar male rats (Rattus norvegicus) weighing $250 \mathrm{~g}$ on average, and 9 weeks of age were distributed into four groups $(\mathrm{n}=8)$, as follows: Control (CTRL); Experimental 1 (G1); Experimental $2(\mathrm{G} 2)$ and Experimental 3 (G3). The experimental groups $\mathrm{G} 1$ and $\mathrm{G} 2$ received $18 \mathrm{mg} / \mathrm{kg}$ body weight (b.w.) of crack cocaine administered by intraperitoneal route (i.p.) per 5 days, once a day. The experimental group G3 received 36 $\mathrm{mg} / \mathrm{kg}$ body weight (b.w.) of crack cocaine administered by intraperitoneal route (i.p.) per 5 days, once a day. Crack cocaine was diluted in dimethylsulfoxide (DMSO). The choice of using DMSO as a vehicle was based on the fact that it is a solvent and a chelating agent, with a high diffusing capacity, easily penetrating all tissues of the organism. To standardize the amount of i.p. injection, the final volume used was $1 \mathrm{ml} / \mathrm{kg}$ for all animals. The dose levels used of crack cocaine correspond to 25\% (18 mg) and 50\% (36 mg) of the cocaine lethal dose to $50 \%$ (LD50) in rodents (12). The animals of groups G1 and G3 were euthanized 5 days after i.p. injection. The animals of group G2 were euthanized $72 \mathrm{~h}$ after the 5 days of i.p. injection.

Mutagenicity and cytotoxicity. The tissues were stained with Feulgen-Fast Green for evaluating mutagenicity and cytotoxicity. For this purpose, the following metanuclear changes were recorded: micronucleated cells, binucleated cells, pyknosis, karryorhexis and karyolyis. A total of 2,000 cells were evaluated per animal.

Immunohistochemistry for 8 OHdG. The anti-8-hydroxy-20deoxyguanosine (8 OHdG, Santa Cruz Biotechnologies Inc. ${ }^{\mathrm{TM}}, \mathrm{MO}$, USA) antibody was used at 1:100 dilution. The analysis was based on scores, taking into account the presence or absence of immunopositive cells as well as the extent of the stained sections as follows: no staining [0], weak staining [1], moderate staining [2], and strong staining [3] (13).
Western blot of Toll like signaling pathway (MyD88, TRAF-6 and $N F K b-p 65)$. Western blot was conducted, as described by Yujra et al. (14). The antibody against pNFkBp65 (sc-101744) was purchased from Santa Cruz Biotechnology ${ }^{\mathrm{TM}}$, Inc. (Santa Cruz, CA, USA). The antibodies against MyD88 (ab2064), TRAF6 (ab33915) and $\beta$-actin (ab9484) were obtained from ABCAM $^{\mathrm{TM}}$ (Cambridge, UK). The intensities of each band sample were quantified by the Image $J^{\mathrm{TM}}$ software (Image $\mathrm{J}^{\mathrm{TM}}$, National Institute of Health, MD, USA). All numerical values were normalized using $\beta$-actin levels in the respective membrane.

Statistical analysis. Data were expressed as mean \pm standard deviation. All analyzes were evaluated by the Kruskal-Wallis nonparametric test followed by Dunn's test. $p<0.05$ was considered to be significant.

\section{Results}

Mutagenicity and cytotoxicity. The groups exposed to crack cocaine had an increase in the number of micronucleated hepatocytes only in the highest tested dose $(36 \mathrm{mg} / \mathrm{kg})$. Statistically significant differences $(p<0.05)$ were detected in the G3 group in relation to the control. The same occurred in the evaluation of the total number of binucleated cells, i.e. significant statistically differences $(p<0.05)$ were detected in the G3 group in relation to the CTLR group. Regarding cytotoxicity, karyolysis had an increase in the dose of 18 $\mathrm{mg} / \mathrm{kg}$ followed by abstinence (G2), with statistically significant difference $(p<0.05)$ when compared to the CTRL group $(p \leq 0.05)$. The group exposed to $36 \mathrm{mg} / \mathrm{kg}$ of crack cocaine also showed an increase in karyolysis, with a statistically significant difference $(p<0.05)$ when compared to the groups CTRL and G1 $(p \leq 0.05)$. Pyknotic hepatocytes had a higher average in the G2 group when compared to the CTRL group, with a statistically significant difference $(p \leq 0.05)$. Karryorhexis did not show any changes among groups. These findings are shown in Table I.

Immunohistochemistry for $8 \mathrm{OHdG}$. Immunohistochemical expression of $8 \mathrm{OHdG}$ was detected both in the cytoplasm and in the nucleus of liver cells. The results showed that G1, which was exposed to $18 \mathrm{mg} / \mathrm{kg}$, increased the expression of this immunomarker when compared to the CTLR group. Statistically differences $(p<0.05)$ were detected between the groups evaluated $(p<0.05)$. The abstinence group (G2) did not show any difference $(p>0.05)$ when compared to the G1 and CTLR groups $(p>0.05)$. The same occurred for the G3 group. Results are shown in Figure 1.

Protein content of Toll like signaling pathway (MyD88, TRAF-6 and NFKb-p65). In the hepatic tissue, the p-NF-kB p65 protein showed a decrease in the groups exposed to crack cocaine at doses of 18 and $36 \mathrm{mg} / \mathrm{kg}$. In a similar manner, the abstinence group (G2) showed significant difference $(p \leq 0.05)$ in relation to the CTRL group. The 
Table I. Metanuclear changes in rat liver induced by crack cocaine.

\begin{tabular}{lccccc}
\hline $\begin{array}{l}\text { Groups } \\
(\mathrm{n}=08)\end{array}$ & Micronucleus & Binucleation & Pyknosis & Karryorhexis & \\
\hline CTRL & & & & \\
G1 & $0.3 \pm 0.5$ & $92.1 \pm 30.2$ & $8.3 \pm 8.3$ & $0.7 \pm 0.8$ & $192.3 \pm 71.0$ \\
G2 & $0.5 \pm 0.7$ & $100.5 \pm 11.7$ & $15.6 \pm 8.3$ & $0.6 \pm 1.1$ & $354.8 \pm 95.5$ \\
G3 & $0.6 \pm 0.5$ & $72.1 \pm 17.5$ & $22.2 \pm 7.6^{*}$ & $0.5 \pm 0.7$ & $421.8 \pm 69.6^{*}$ \\
\hline
\end{tabular}

Values are shown as mean \pm S.D. Control group (CTRL); Crack cocaine $18 \mathrm{mg} / \mathrm{kg}$ group (G1); Crack cocaine $18 \mathrm{mg} / \mathrm{kg}$ and $72 \mathrm{~h}$ after exposure (abstinence) group (G2); Crack cocaine $36 \mathrm{mg} / \mathrm{kg}$ group (G3). * $p \leq 0.05$ when compared to CTLR.

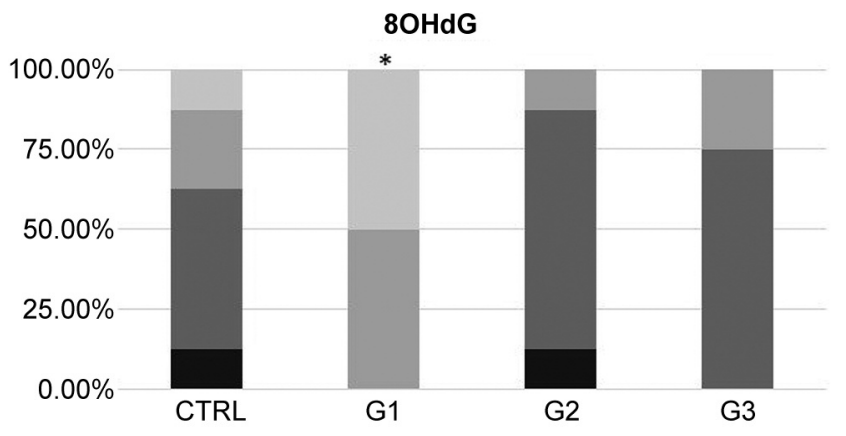

- SCORE $0 \backsim$ SCORE 1 -SCORE 2 SCORE 3

Figure 1. Scoring of 8 OHdG immunoexpression in rat liver exposed to crack cocaine. Control group (CTRL); Crack cocaine $18 \mathrm{mg} / \mathrm{kg}$ group (G1); Crack cocaine $18 \mathrm{mg} / \mathrm{kg}$ at $72 \mathrm{~h}$ after exposure (abstinence) group (G2); Crack cocaine $36 \mathrm{mg} / \mathrm{kg}$ group (G3). * $p \leq 0.05$ when compared to CTLR.

MyD88 protein also showed a decrease in the groups exposed to crack cocaine at the dose of $18 \mathrm{mg} / \mathrm{kg}(p \leq 0.05)$. Crack cocaine was not able to modulate the expression of TRAF-6 $(p>0.05)$ in liver for all groups studied. These findings are demonstrated in Figure 2.

\section{Discussion}

The aim of the study was to evaluate cytogenetic damage, genomic oxidative stress and toll like signaling pathway in rat liver exposed to crack cocaine. First, our results demonstrated that crack cocaine at $36 \mathrm{mg} / \mathrm{kg}$ dose was able to induce mutagenicity by means of increased numbers of both micronucleated and binucleated cells in rat liver. Moreover, our results revealed that karyolysis was increased by crack cocaine at $36 \mathrm{mg} / \mathrm{kg}$. In mice, the hepatotoxic potential of cocaine was evaluated at different doses and periods of time. After 24 and $48 \mathrm{~h}$ of drug administration, areas of necrosis in the liver parenchyma were observed. A dose of $50 \mathrm{mg} / \mathrm{kg}$ of cocaine induced hepatic tissue regeneration after 3-5 days of administration (15). Shi et al. (16) observed in a study with mice, necrotic areas in hepatic tissue as well. In this study, the mice received $30 \mathrm{mg} / \mathrm{kg}$ of by i.p route, once a day during 3 days. Our results are fully in line with previous reports since the presence of karyolysis in rat liver has been closely related to cellular death by necrosis.

In humans, it has been demonstrated that crack cocaine increases the total number of micronucleus in buccal mucosa cells $(7,8)$. The same results were found in human lymphocytes (17). Recently, others have assumed that crack cocaine altered the proliferative activity of buccal mucosa cells as a result of decreasing the number of AgNORs positive cells (18). However, our experimental group that remained $72 \mathrm{~h}$ without the administration of crack cocaine after the 5 days of treatment (G2) increased the total number of pyknotic cells when compared to control group. Taken as a whole, it seems that the abstinence period after crack cocaine exposure was able to induce cell death as a result of apoptosis. This finding is particularly important, because it is consistent with notion that damaged hepatocytes are disposed from the liver parenchyma by apoptosis after finishing the crack cocaine exposure.

$8 \mathrm{OHdG}$ is one of the markers used to identify oxidative damage to DNA, because among the various by-products generated during oxidative damage to DNA, changes in nitrogenous bases are synthetized in vivo and can be evaluated after DNA damage (19). The formation of $8 \mathrm{OHdG}$ occurs due to the oxidation of the nitrogenous guanine base, with the addition of $\mathrm{HO} \bullet$ in the 8-position carbon, giving rise to a DNA adduct, C8-hydroxy-guanine (8 OHGua). After this process, this molecule ends up losing electrons, giving rise to 8 OHdG (20). Our results demonstrated that immunoexpression for $8 \mathrm{OHdG}$ increased in the group exposed to crack cocaine at $18 \mathrm{mg} / \mathrm{kg}$ only. In humans, a study conducted by Bacchi et al. (20), found that regular cocaine users had an increase of $8 \mathrm{OHdG}$ in urine. In rats, previous studies by our research group showed that a single dose of $18 \mathrm{mg} / \mathrm{kg}$ of crack cocaine was able to induce the formation of $8 \mathrm{OHdG}$ in hepatocytes (5). The groups $\mathrm{G} 2$ (abstinence) and G3 (36 mg/kg) did not show remarkable differences when compared to control. It is important to 


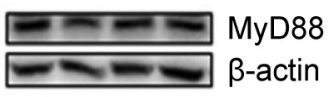

150

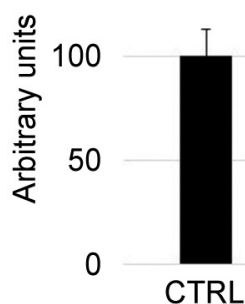

G1

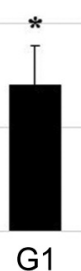

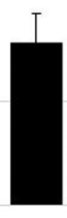

G2

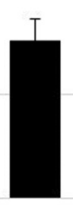

G3

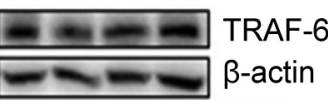

150

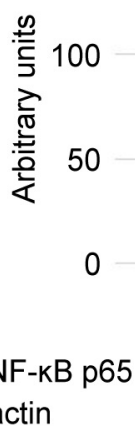

200

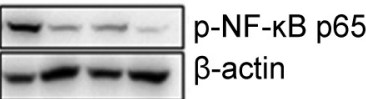

CTRL
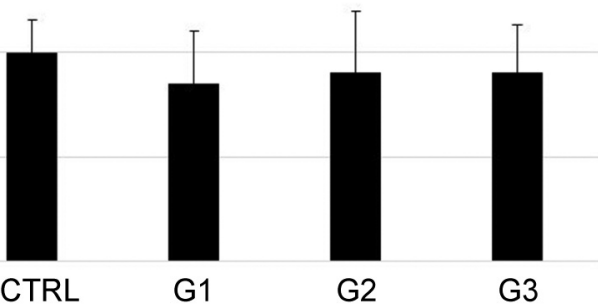

G3

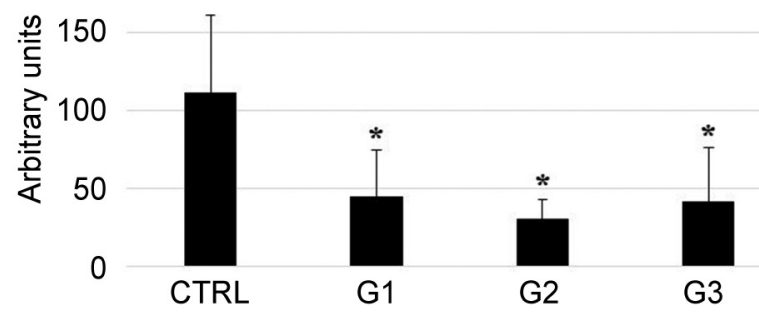

Figure 2. Toll-like signaling pathway (MyD88, TRAF-6 e p-NF-kB p65) in rat liver exposed to crack cocaine. Control group (CTRL); Crack cocaine $18 \mathrm{mg} / \mathrm{kg}$ group (G1); Crack cocaine $18 \mathrm{mg} / \mathrm{kg}$ and $72 \mathrm{~h}$ after exposure (abstinence) group (G2); Crack cocaine $36 \mathrm{mg} / \mathrm{kg}$ group (G3). *p $\leq 0.05$ when compared to CTLR.

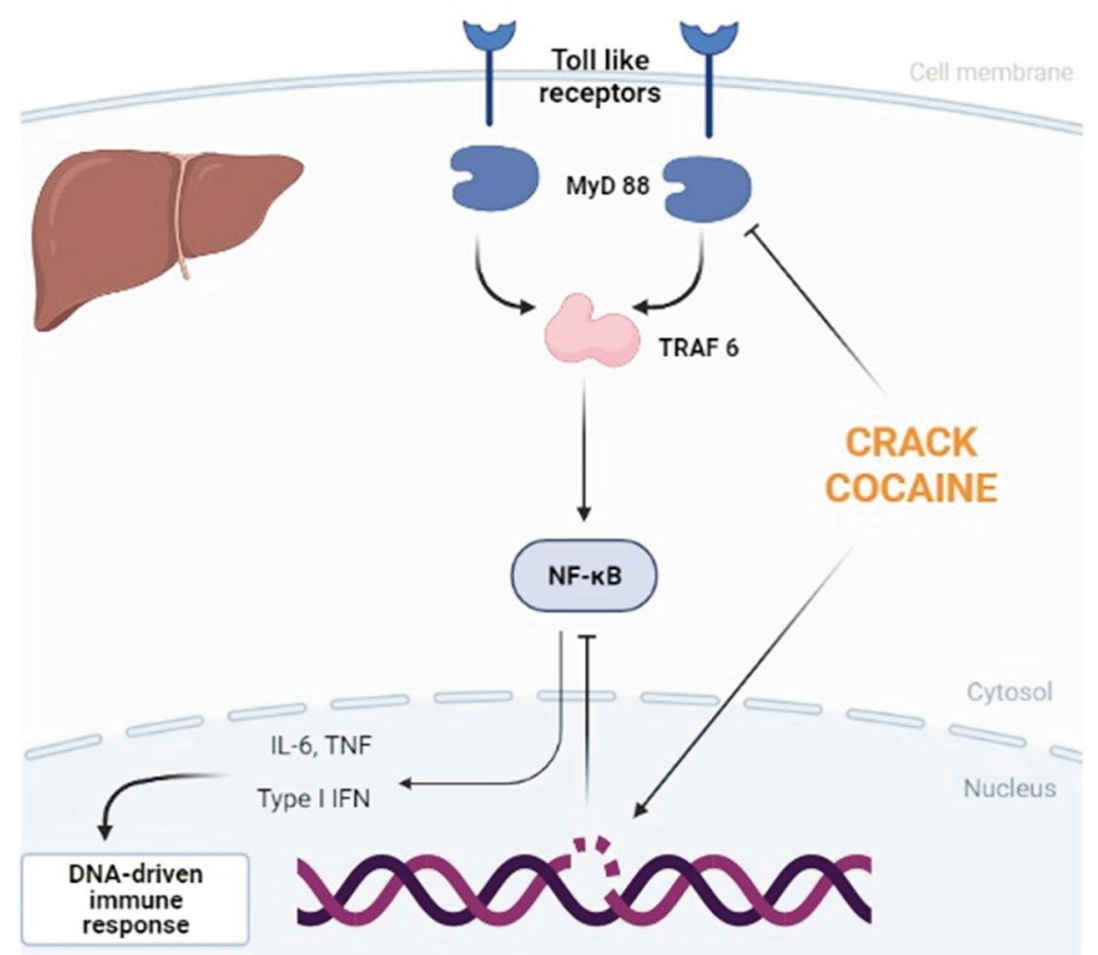

Figure 3. Pathobiological effects of crack cocaine in the toll like signaling pathway as a result of genomic instability in liver cells. 
highlight that increased levels of $8 \mathrm{OHdG}$ are correlated with the development of several pathologies, including cancer.

Regarding Toll like signaling pathway, our findings demonstrated, for the first time, that MyD88 protein expression decreased in the group exposed to $18 \mathrm{mg} / \mathrm{kg}$ of crack cocaine. With regard to NFKB-p65 protein expression, it also decreased in all experimental groups exposed to crack cocaine (18 mg/kg and/or abstinence and $36 \mathrm{mg} / \mathrm{kg}$ groups $)$. Therefore, we assume that crack cocaine inhibited the toll like signaling pathway denoting the immunosuprressive effects in hepatocytes. Conversely, some authors showed that cocaine significantly increased the levels of MyD88, IRAK1, and TRAF6 in mice microglial cells $(21,22)$. Further studies are required to elucidate the issue, especially to clarify the real impact of toll like signaling proteins in different tissues and organs exposed to crack cocaine.

In conclusion, our results demonstrated that crack cocaine inhibited toll like signaling pathway whilst being associated with genomic instability in rat liver cells (Figure 3 ).

\section{Conflicts of Interest}

The Authors declare no conflicts of interest.

\section{Authors' Contributions}

DVS, BAR and ITM performed the experimental design. DVS, ITM and BAR performed immunohistochemistry experiments. DVS and DAR evaluated the micronuclei. DVS, LVM and LPP performed western blot experiments. All Authors interpreted the results and wrote the manuscript.

\section{Acknowledgements}

The Authors acknowledge Research Grants received from $\mathrm{CNPq}$ (Conselho Nacional de Desenvolvimento Cientifico e Tecnológico) and CAPES (Coordenação de Aperfeiçoamento de Pessoal de Nível Superior). DVS and BAR thanks CAPES for grants received scholarship. LPP, MBV and DAR thanks CNPq for productivity fellowships.

\section{References}

1 Riezzo I, Fiore C, De Carlo D, Pascale N, Neri M, Turillazzi E and Fineschi V: Side effects of cocaine abuse: multiorgan toxicity and pathological consequences. Curr Med Chem 19(33): 5624-5646, 2012. PMID: 22934772. DOI: 10.2174/ 092986712803988893

2 Oliveira NG and Dinis-Oliveira RJ: Drugs of abuse from a different toxicological perspective: an updated review of cocaine genotoxicity. Arch Toxicol 92(10): 2987-3006, 2018. PMID: 30116851. DOI: 10.1007/s00204-018-2281-1

3 Chaves TV, Sanchez ZM, Ribeiro LA and Nappo SA: Crack cocaine craving: behaviors and coping strategies among current and former users. Rev Saude Publica 45(6): 1168-1175, 2011. PMID: 21894428. DOI: 10.1590/s0034-89102011005000066
4 Andrade Filho A, Campolina D and Dias MB: Toxicologia na prática clinica. 2 aed. Belo Horizonte: Folium, 2013.

5 Moretti EG, Yujra VQ, Claudio SR, Silva MJ, Vilegas W, Pereira $\mathrm{CD}$, de Oliveira $\mathrm{F}$ and Ribeiro DA: Acute crack cocaine exposure induces genetic damage in multiple organs of rats. Environ Sci Pollut Res Int 23(8): 8104-8112, 2016. PMID: 26825523. DOI: $10.1007 / \mathrm{s} 11356-016-6141-3$

6 Yujra VQ, Moretti EG, Claudio SR, Silva MJ, Oliveira Fd, Oshima CT and Ribeiro DA: Genotoxicity and mutagenicity induced by acute crack cocaine exposure in mice. Drug Chem Toxicol 39(4): 388-391, 2016. PMID: 26712310. DOI: 10.3109/ 01480545.2015.1126843

7 Antoniazzi RP, Lago FB, Jardim LC, Sagrillo MR, Ferrazzo KL and Feldens CA: Impact of crack cocaine use on the occurrence of oral lesions and micronuclei. Int J Oral Maxillofac Surg 47(7): 888-895, 2018. PMID: 29336931. DOI: 10.1016/j.ijom. 2017.12.005

8 das Graças Alonso de Oliveira M, Dos Santos JN, Cury PR, da Silva VH, Oliveira NR, da Costa Padovani R, Tucci AM and Ribeiro DA: Cytogenetic biomonitoring of oral mucosa cells of crack cocaine users. Environ Sci Pollut Res Int 21(8): 5760-5764, 2014. PMID: 24430497. DOI: 10.1007/s11356-013-2447-6

9 Pisani LP, Estadella D and Ribeiro DA: The role of toll like receptors (TLRs) in oral carcinogenesis. Anticancer Res 37(10): 5389-5394, 2017. PMID: 28982847. DOI: 10.21873/anticanres. 11965

10 Montagud-Romero S, Reguilón MD, Pascual M, Blanco-Gandía MC, Guerri C, Miñarro J and Rodríguez-Arias M: Critical role of TLR4 in uncovering the increased rewarding effects of cocaine and ethanol induced by social defeat in male mice. Neuropharmacology 182: 108368, 2021. PMID: 33132187. DOI: 10.1016/j.neuropharm.2020.108368

11 Zhu R, Bu Q, Fu D, Shao X, Jiang L, Guo W, Chen B, Liu B, Hu Z, Tian J, Zhao Y and Cen X: Toll-like receptor 3 modulates the behavioral effects of cocaine in mice. J Neuroinflammation 15(1): 93, 2018. PMID: 29571298. DOI: 10.1186/s12974-018$1130-8$

12 Salvadori DM, Barbisan LF, Bazo AP, de Santana EQ, Denadai R, de Oliveira SV, Ribeiro LR and de Camargo JL: Cocaine mutagenicity and hepatocarcinogenicity evaluations in rodents. Teratog Carcinog Mutagen 18(4): 199-208, 1998. PMID: 9804275. DOI: 10.1002/(sici)1520-6866(1998)18:4<199::aidtcm5>3.0.co;2-s

13 Claudio SR, Pidone Ribeiro FA, De Lima EC, Santamarina AB, Pisani LP, Pereira CSD, Fujiyama Oshima CT and Ribeiro DA: The protective effect of grape skin or purple carrot extracts against cadmium intoxication in kidney of rats. Pathophysiology 26(3-4): 263-269, 2019. PMID: 31924351. DOI: 10.1016/ j.pathophys.2019.07.001

14 Yujra VQ, Antunes HKM, Mônico-Neto M, Pisani LP, Santamarina AB, Quintana HT, de Oliveira F, Oshima CTF and Ribeiro DA: Sleep deprivation induces pathological changes in rat masticatory muscles: Role of Toll like signaling pathway and atrophy. J Cell Biochem 119(2): 2269-2277, 2018. PMID: 28857246. DOI: $10.1002 /$ jcb.26389

15 Shuster L, Quimby F, Bates A and Thompson ML: Liver damage from cocaine in mice. Life Sci 20(6): 1035-1041, 1977. PMID: 850458. DOI: 10.1016/0024-3205(77)90291-0

16 Shi X, Yao D, Gosnell BA and Chen C: Lipidomic profiling reveals protective function of fatty acid oxidation in cocaine- 
induced hepatotoxicity. J Lipid Res 53(11): 2318-2330, 2012. PMID: 22904346. DOI: 10.1194/jlr.M027656

17 de Freitas TA, Palazzo RP, de Andrade FM, Reichert CL, Pechansky F, Kessler F, de Farias CB, de Andrade GG, LeistnerSegal S and Maluf SW: Genomic instability in human lymphocytes from male users of crack cocaine. Int J Environ Res Public Health 11(10): 10003-10015, 2014. PMID: 25264678. DOI: $10.3390 /$ ijerph111010003

18 Góes Rabelo R, Salgueiro AP, Visioli F, da Silva VP, das Graças Alonso Oliveira M, Ribeiro DA, Cury PR and Dos Santos JN: Argyrophilic nucleolar organizer regions in oral mucosa cells of crack and cocaine users: a cross-sectional study. Environ Sci Pollut Res Int 27(30): 37920-37926, 2020. PMID: 32617811. DOI: $10.1007 / \mathrm{s} 11356-020-09892-\mathrm{w}$

19 Valavanidis A, Vlachogianni T and Fiotakis C: 8-hydroxy-2' deoxyguanosine (8-OHdG): A critical biomarker of oxidative stress and carcinogenesis. J Environ Sci Health C Environ Carcinog Ecotoxicol Rev 27(2): 120-139, 2009. PMID: 19412858. DOI: $10.1080 / 10590500902885684$
20 Bacchi S, Palumbo P, Di carlo M and Coppolino M: Cocaine effects on generation of reactive oxygen species and DNA damage: formation of 8-hydroxydeoxyguanosine in active abusers. International Journal of Pharmacology and Toxicology 4(2): 138, 2016. DOI: 10.14419/ijpt.v4i2.5970

21 Chivero ET, Liao K, Niu F, Tripathi A, Tian C, Buch S and Hu G: Engineered extracellular vesicles loaded with miR-124 attenuate cocaine-mediated activation of microglia. Front Cell Dev Biol 8: 573, 2020. PMID: 32850781. DOI: 10.3389/fcell. 2020.00573

22 Periyasamy P, Liao K, Kook YH, Niu F, Callen SE, Guo ML and Buch S: Cocaine-mediated downregulation of miR-124 activates microglia by targeting KLF4 and TLR4 signaling. Mol Neurobiol 55(4): 3196-3210, 2018. PMID: 28478506. DOI: $10.1007 / \mathrm{s} 12035-017-0584-5$

Received March 19, 2021

Revised May 31, 2021

Accepted June 3, 2021 